\title{
Market Acceptability Study of Vacuum-fried Chicken (Gallus gallus domesticus L.) "Isaw"
}

\author{
Anastacio T. Cagabhion III ${ }^{1 \star}$, Ivy C. Emnace ${ }^{2}$ and Nilda T. Amestoso ${ }^{3}$
}

\begin{abstract}
Chicken "isaw"is a traditional food in the market that has been widely accepted by the low-income segment of the Filipino populace. Chicken "isaw" was developed into a more hygienic product through vacuum frying to improve its quality, shelf life, and marketability. Market acceptability assessment of the improved product was done by involving both consumers and non-consumers of chicken "isaw." Results of which showed that $93 \%$ of non-consumers were aware about the traditional chicken "isaw" but were not buying or consuming the product due to perceptions that the product is unsafe, unhygienic, and unpalatable. Results also showed that consumers purchased the product due to its affordability, availability, and palatable taste. The product was purchased weekly by a little less than $50 \%$ of the consumers, buying 4 to 6 pieces. Results revealed that all the consumer and non-consumer respondents were not aware of the improved chicken "isaw." However, $90 \%$ of consumers and $52 \%$ of non-consumers were willing to purchase the product. Moreover, $87 \%$ of consumers and $100 \%$ of non-consumers preferred vacuum fried chicken "isaw" compared to the conventionally fried one. Suggestions regarding the marketing mix strategies include: a.) offering the product in variants of different flavors; b.) improvement of color and texture; c.) development of appropriate packaging; d.) offering the product in small affordable packs, and; e.) making the product available in food courts, supermarkets, and canteens. In addition, product promotion in radio stations, social media, as well as other online sites and giving free samples, fliers, and posters were also suggested.
\end{abstract}

Keywords: chicken "isaw", market acceptability, vacuum frying

\section{INTRODUCTION}

"Isaw" is a fried or grilled chicken intestine traditionally consumed by Filipinos. It has been in the market particularly as street food for a considerable time. The demand for chicken "isaw" stems from its availability and affordability with a price of PhP 20.00 (0.40 USD) per 50 grams. However, people are wary of consuming this product because of food safety issues, short shelf-life, and keeping qualities. In

\footnotetext{
${ }^{1}$ Western Philippines University, San Juan, Aborlan, Palawan

${ }^{2}$ Visayas State University, Department of Food Science and Technology, Visca, Baybay City, Leyte, Philippines 3Visayas State University, Department of Business Management, Visca, Baybay City, Leyte, Philippines

${ }^{*}$ Corresponding Author : Address: West Philippines University, San Juan, Aborlan, Palawan. E-mail: nashjayahr@gmail.com
} 
order to address these issues, a new product was created through vacuum frying technology. The product was developed following the Response Surface Methodology (RSM) by screening and optimizing the variables that significantly influenced its quality in order to come up with optimum formulation. In addition, assessment of its shelf-life and quality was also done because it has to be massproduced. However, market acceptability of the newly developed product was still undetermined. Hence, this study.

Market acceptability of a new product is a challenge for entrepreneurs because the failure rate is high and costly. Thus, it is important to determine what consumers prefer when they buy a new product (Arabadzhieva 2016). New product introduction can be studied from two perspectives: the entrepreneur's side and the consumer's side. For the entrepreneur's side, the innovation process starts with generating a creative idea and developing a concept for a product. This is followed by the new product development process, which transforms the idea into a product ready for the marketplace. After which, the product is finally launched (Annacchino 2003; Trott 2008). Meanwhile, studying the consumer's perspectives for a new product introduction is elaborated in this study. Hence, the general objective of this study is to determine the market acceptability of the newly developed vacuum fried chicken "isaw." Specifically, this study aimed to: a.) profile the consumers and nonconsumers of chicken "isaw" in Baybay City, Leyte; b.) describe the buying habit of both consumers and non-consumers; c.) determine the response of nonconsumers towards the newly developed product, and; d.) provide recommendations in formulating the marketing mix strategies of the vacuum fried chicken "isaw."

\section{MATERIALS AND METHODS}

\section{Locale and Sampling Procedure of the Study}

A total of 200 respondents were selected for the market acceptability study. One hundred were consumers of the conventionally fried chicken "isaw," while the other hundred were non-consumers. The study was conducted at Baybay City Food Park. All the respondents were asked to taste a sample of the product and immediately fill out the questionnaire. The interviewer interpreted the questionnaire into the local dialect for respondents who did not speak English or had minimal formal education. The instrument was composed of six parts. The first part contained the demographic profile of respondents in terms of age, sex, and monthly income. The second part was designed to determine their awareness of the conventionally fried chicken "isaw" and their source of information on the product. The third part covered their product purchase which includes where they bought the conventionally fried chicken "isaw"; how frequently they bought the product; the quantity of the product during purchase; and why they purchase the 
product. The fifth part determined their awareness of the newly developed vacuum fried chicken "isaw." The sixth part elicited their comments on the vacuum fried chicken "isaw."

\section{Data Collection and Analysis}

The data on profile, buying habit, and consumer preferences of both consumer and non-consumer respondents were gathered using a questionnaire. Additional data were gathered from the non-consumers to determine the reasons why they did not consume chicken "isaw" and their response towards the newly developed vacuum fried chicken "isaw." Data obtained from the survey were analyzed statistically using SPSS version 17.0.

\section{RESULTS AND DISCUSSION}

\section{Profile of Respondents}

There were 200 respondents interviewed: 100 "isaw" consumers and 100 nonconsumers where $42.5 \%$ were males and $57.5 \%$ were females (Table 1 ) with ages ranging from 10 to 61 years old. Respondents were also classified according to their monthly income based on the indicative range of monthly income of Filipinos published by Albert et al (2015) to help segment the subgroups in the possible market. Results show that $47 \%$ are low-income consumers with a monthly income of PhP 10,000 or less. On the other hand, for the non-consumers, one-third belongs to the low-income group, and another third belongs to the lower middle-income group with salaries between PhP 20,000 to PhP 30,000.

Table 1. Gender and monthly income of the respondents of chicken "isaw"

\begin{tabular}{lcrrrrr}
\hline & \multicolumn{2}{c}{ Consumers } & \multicolumn{2}{c}{ Non-Consumers } & \multicolumn{2}{c}{ Total } \\
\cline { 2 - 7 } & Freq & Percent & Freq & Percent & Freq & Percent \\
\hline Gender & 35 & 35.0 & 50 & 50.0 & 85 & 42.5 \\
$\quad$ Male & 65 & 65.0 & 50 & 50.0 & 115 & 57.5 \\
$\quad$ Female & 100 & 100.0 & 100 & 100.0 & 200 & 100.0 \\
Total & & & & & & \\
& & & & & & \\
Monthly income & 47 & 47.0 & 33 & 33.0 & 80 & 40.0 \\
$\quad 10,000$ or less & 23 & 23.0 & 22 & 22.0 & 45 & 22.5 \\
10,001 to 20,000 & 25 & 25.0 & 33 & 33.0 & 58 & 29.0 \\
20,001 to 30,000 & 5 & 5.0 & 12 & 12.0 & 17 & 8.5 \\
30,000 and above & 100 & 100.0 & 100 & 100.0 & 200 & 100.0 \\
Total & & & & &
\end{tabular}


Table 2 shows the correlation between the consumption of chicken "isaw" to the gender and monthly income of the respondents. Based on the results, gender has a significant effect on the decision of buying or consuming chicken "isaw." This corresponds to the figure shown in Table 1 where more females consume chicken "isaw" than that of men. Moreover, as shown in Table 2, p-value for the monthly income is less than 0.05 which indicates that monthly income and consumption of chicken "isaw" has a significant positive relationship. It can be observed that almost half ( $47 \%)$ of the consumer respondents have low income (Table 1 ).

Table 2. Analysis of variance for the gender and monthly income of respondents

\begin{tabular}{lccccc}
\hline & SS & MS & df & F & p \\
\hline Gender & 1.150895 & 1.150895 & 1 & 4.664921 & $0.031987^{\star}$ \\
Monthly Income & 1.578332 & 1.578332 & 1 & 6.453924 & $0.011838^{\star}$ \\
\hline
\end{tabular}

*-significant at $\mathrm{p}<0.05$

\section{Awareness and Sources of Awareness of Chicken "Isaw"}

Table 3 shows that all the consumers and $93 \%$ of the non-consumers were aware of chicken "isaw." This is because the product has been in the market for a long time and bought primarily by the low-income segment. Its wide availability makes the product highly visible to people.

Table 3. Awareness of the respondents on the conventionally fried chicken "isaw"

\begin{tabular}{lcccc}
\hline & \multicolumn{2}{c}{ Consumers } & \multicolumn{2}{c}{ Non-consumers } \\
\cline { 2 - 5 } & Frequency & Percentage & Frequency & Percentage \\
\hline Yes & 100 & 100 & 93 & 93 \\
No & - & 0 & 7 & 7 \\
Total & 100 & 100 & 100 & 100 \\
\hline
\end{tabular}

The respondents had several sources of information on the conventionally fried chicken "isaw." A greater portion of consumers obtained information from friends and colleagues (47\%) and market outlets (43\%), while most of the nonconsumers $(58 \%)$ said that they knew about chicken "isaw" through their colleagues or friends (Table 4).

Table 4. Respondents' sources of information on chicken "isaw"

\begin{tabular}{lcccc}
\hline & \multicolumn{2}{c}{ Consumers $^{*}$} & \multicolumn{2}{c}{ Non-consumers } \\
\cline { 2 - 5 } & Frequency & $\begin{array}{c}\text { Percentage } \\
(\%)\end{array}$ & Frequency & $\begin{array}{c}\text { Percentage } \\
(\%)\end{array}$ \\
\hline Colleagues/friends & 52 & 47.3 & 60 & 57.7 \\
Communication media & 3 & 2.7 & 0 & 0.0 \\
Trade fairs/food expo & 8 & 7.3 & 12 & 11.5 \\
Market outlets & 47 & 42.7 & 32 & 30.8 \\
Total & 110 & 100.0 & 104 & 100.0 \\
\hline
\end{tabular}

*-Multiple response 


\section{Reasons for Not Buying Chicken "Isaw"}

Non-consumers reasons for not buying chicken "isaw" include the perceptions that the product is unsafe and unhygienic (41\%), unhealthy $(37 \%)$, and unpalatable (22\%) (Table 5). This can be linked to the monthly income of the non-consumers of chicken "isaw" (Table 1 \& Table 2) wherein more than half of them had a monthly income greater than Php 10,000. This means that they have the capability of choosing a wider array of food which they perceive to be healthier, more palatable, and produced safely.

Table 5. Reasons for not buying chicken "isaw"

\begin{tabular}{lcc}
\hline & Frequency* & Percent \\
\hline Unhealthy & 38 & 37.2 \\
Unsafe/Unhygienic & 42 & 41.2 \\
Unpalatable & 22 & 21.6 \\
Total & 102 & 100.0 \\
\hline
\end{tabular}

*- Multiple response

\section{Product Purchase}

The majority (71\%) of the consumers purchased chicken "isaw" from street vendors (Table 6) since street vendors are commonly found outside the gates of schools and offices. In addition, as shown in Table 7, a greater proportion of the consumers (32\%) purchased chicken "isaw" once a week, consuming 4 to 6 pieces at a time.

Table 6. Respondents' sources of chicken "isaw"

\begin{tabular}{lcc}
\hline & Frequency* & Percentage \\
\hline Street Vendors & 79 & 71.2 \\
Canteen & 6 & 5.4 \\
Public Market & 26 & 23.4 \\
Total & 111 & 100.0 \\
\hline *-Multiple response & &
\end{tabular}

Table 7. Respondents' consumption of chicken "isaw"

\begin{tabular}{lccccc}
\hline \multirow{2}{*}{ Consumption } & \multicolumn{5}{c}{ Frequency (No. of pieces) } \\
\cline { 2 - 6 } & $1-3$ & $4-6$ & $6-10$ & More than 10 & Total \\
\hline Once a day & 11 & 1 & 1 & 1 & 14 \\
Twice a day & 4 & 3 & 5 & - & 12 \\
Once a week & 7 & 32 & 2 & 1 & 42 \\
Once a month & 7 & - & 5 & 3 & 15 \\
Twice a month & 8 & 2 & 3 & 2 & 15 \\
Thrice a week & - & 1 & - & - & 1 \\
Twice a week & - & 1 & - & - & 1 \\
Total & 37 & 40 & 16 & 7 & 100 \\
\hline
\end{tabular}


Table 8 shows that more consumers purchased chicken "isaw" because of its affordability $(47 \%)$ and palatable taste $(42 \%)$. This can be associated with the monthly income of the consumers (Table 2), who mostly had PhP 10,000.00 and below. Consumers buy "isaw", especially the low-income segment, because at a low price, the product can also be consumed as a viand during meals.

Table 8. Respondent's reasons for purchasing chicken "isaw"

\begin{tabular}{lcc}
\hline & Frequency & Percentage \\
\hline Affordable price & 59 & 47.2 \\
Availability & 12 & 9.6 \\
Good taste & 53 & 42.4 \\
High nutritional value & 1 & 0.8 \\
Total & 125 & 100.0 \\
\hline
\end{tabular}

\section{Awareness of Vacuum Fried Chicken "Isaw"}

The survey results revealed that all of the respondents from both the consumer and non-consumer groups have not heard or seen vacuum fried chicken "isaw" before because this was a newly developed product (Table 9). From this information, marketing strategies can be developed for the product to penetrate the market.

Table 9. Respondents' awareness of vacuum fried chicken "isaw"

\begin{tabular}{lcccccc}
\hline & \multicolumn{2}{c}{ Aware } & \multicolumn{2}{c}{ Unaware } & \multicolumn{2}{c}{ Total } \\
\cline { 2 - 7 } & Freq & Percent & Freq & Percent & Freq & Percent \\
\hline Consumers & - & - & 100 & 50 & 100 & 50 \\
Non-consumers & - & - & 100 & 50 & 100 & 50 \\
Total & - & - & 200 & 100 & 200 & 100 \\
\hline
\end{tabular}

The respondents were asked to evaluate the product and their willingness to purchase it. Table 10 summarizes the respondents' (both consumers and nonconsumers) willingness to purchase the newly developed vacuum fried chicken "isaw." The results showed that $90 \%$ of the consumers and more than half $(52 \%)$ of non-consumers were willing to purchase the newly developed vacuum fried chicken "isaw" as they perceived the product to have a crunchy texture, just the right saltiness, and is less oily.

Table 10. Willingness of the respondents to buy vacuum fried chicken "isaw"

\begin{tabular}{lcccccc}
\hline & \multicolumn{2}{c}{ Consumers } & \multicolumn{2}{c}{ Non-consumers } & \multicolumn{2}{c}{ Total } \\
\cline { 2 - 7 } & Freq & Percent & Freq & Percent & Freq & Percent \\
\hline Yes & 90 & 90 & 52 & 52 & 142 & 71 \\
No & 10 & 10 & 48 & 48 & 58 & 29 \\
Total & 100 & 100 & 100 & 100 & 200 & 100 \\
\hline
\end{tabular}




\section{Respondents'preference}

Table 11 shows that respondents preferred the vacuum fried chicken "isaw" over the conventionally fried chicken "isaw." The results reveal that $87 \%$ of the respondents from the consumer group preferred the vacuum fried chicken "isaw" to the conventionally fried product since the vacuum fried chicken "isaw" has a more palatable taste and aroma. Moreover, all of the respondents from the non-consumer group preferred the vacuum fried chicken "isaw" as they perceived the product to be safe because it was processed through vacuum frying and palatable with no pungent aroma.

Table 11. Respondents' preference between conventionally fried chicken "isaw" and vacuum fried chicken "isaw"

\begin{tabular}{lcccccc}
\hline & \multicolumn{2}{c}{ Consumers } & \multicolumn{2}{c}{ Non-Consumers } & \multicolumn{2}{c}{ Total } \\
\cline { 2 - 7 } & Freq & Percent & Freq & Percent & Freq & Percent \\
\hline CFCl & 13 & 13 & 0 & 0 & 13 & 8.6 \\
VFCl & 87 & 87 & 52 & 100 & 139 & 91.4 \\
Total & 100 & 100 & 52 & 100 & 152 & 100 \\
\hline
\end{tabular}

Legend: $\quad \mathrm{CFCl}$ - Conventionally Fried Chicken "Isaw" , VFCl - Vacuum Fried Chicken "Isaw"

\section{Suggestions for the Vacuum Fried Chicken Isaw's Marketing Mix}

Suggestions regarding the 4Ps (product, price, place, and promotion) of the marketing mix were also gathered (Table 12). For the product suggestion, $58 \%$ of the respondents said that the vacuum fried chicken "isaw" should be offered in different flavors such as spicy, cheese, and garlic. Others suggested that its color should be improved (18\%) and that appropriate packaging should be developed as chicken "isaw" currently available in the market does not have any packaging (21\%). For the price, the majority (63\%) suggested that the selling price should not be greater than Php 50.00 per 50 gram-pack while $37 \%$ said that there should be smaller and more affordable packs. A little less than $50 \%$ of the respondents suggested that the product be made available in food courts, supermarkets (32\%), and department stores (22\%). Moreover, more than half (56\%) of the respondents recommended that the product be promoted in social media and other online sites. Finally, $37 \%$ of the respondents suggested that free samples, fliers, and posters must be distributed. 
Table 12. Respondents' recommendations for the vacuum fried chicken "isaw"

\begin{tabular}{lrr}
\hline & Frequency & Percentage \\
\hline Product & 15 & 18.3 \\
$\quad$ Improve the color & 2 & 2.4 \\
Improve the texture & 48 & 58.6 \\
$\quad$ Provide variant flavors & 17 & 20.7 \\
$\quad$ Provide appropriate packagin! & 82 & 100.0 \\
Total & & \\
Price & 64 & 37.4 \\
$\quad$ Small packs should be made & & \\
$\quad$ available to be affordable & 107 & 62.6 \\
$\quad \begin{array}{l}\text { Price should not be greater } \\
\text { than 50 pesos per 50 grams }\end{array}$ & 171 & 100.0 \\
Total & & \\
Place of distribution & 29 & 22.0 \\
$\quad$ Supermarkets & 61 & 46.2 \\
$\quad$ Food Courts & 42 & 31.8 \\
$\quad$ Canteens & 132 & 100.0 \\
Total & & \\
Promotion & 95 & 56.2 \\
$\quad$ Social media/online sites & 62 & 36.7 \\
$\quad$ Free samples and provide & 12 & 7.1 \\
$\quad$ fliers and posters & 169 & 100.0 \\
$\quad$ Radio Stations &
\end{tabular}

\section{CONCLUSION AND RECOMMENDATIONS}

From the results of the study, $90 \%$ of the consumers and $52 \%$ of the nonconsumers preferred the vacuum fried chicken "isaw". They were willing to buy the product as it was more palatable compared to that of the conventionally fried chicken "isaw." This means that the majority of the respondents, regardless of the subgroups, are possible consumers of the vacuum fried chicken "isaw" and that there is a potential for the newly developed product in Baybay City. In addition, respondents' recommendations should also be taken into consideration on the improvement of the product. It is suggested that further studies on the development of various flavors and packaging the product into small packs should be conducted.

\section{REFERENCES}

Albert JRG, Gaspar RE \& Raymundo MJM. 2015. Why we should pay attention to the middle class. Philippine Institute for Development Studies. Policy Notes No. 2015-13.

Annacchino MA. 2003. New Product Development: from Initial Idea to Product Management. Amsterdam: Butterworth-Heinemann. 
Arabadzhieva I. 2016. New products: the importance of product characteristics in the buying process depending on the product type. Master Thesis. Erasmus School of Economics.

Burt S, Johansson U \& Thelander A. 2011. Standardized marketing strategies in retailing? IKEA's marketing strategies in Sweden, the UK and China. Journal of Retailing and Consumer Services 18(3):183-193

Rezvani Z. 2009. New Product Development Based on Customer Management Knowledge. Master's Thesis. Department of Business Administration and Social Sciences. Division of Industrial Marketing and e-commerce.

Schmid S and Kotulla T. 2011. 50 years of research on international standardization and adaptation - From a systematic literature analysis to a theoretical framework. International Business Review.

Trott P. 2008. Innovation Management and New Product Development. Harlow, England: Financial Times/Prentice Hall.

Tseltsova A and Bohnert K. 2015. The international marketing strategy of grocery retailers - the strategy of adaptation and standardization. Student Thesis. Dalarna University. 